\title{
Irritable bowel syndrome: Is it "irritable brain" or "irritable bowel"?
}

\author{
Susanta Kumar Padhy, Swapnajeet Sahoo, Sonali Mahajan, Saroj Kumar Sinha ${ }^{1}$ \\ Departments of Psychiatry and ${ }^{1}$ Gastroenterology, Postgraduate Institute of Medical Education and Research, Chandigarh, India
}

\begin{abstract}
Irritable bowel syndrome (IBS) has been recognized as one of the most common and best studied disorders among the group of functional gastrointestinal disorders. It is a functional bowel disorder in which abdominal pain or discomfort is associated with defecation or a change in bowel habit. In the Western world, IBS appears to affect up to $20 \%$ of the population at any given time but in Asian countries, the median value of IBS prevalence defined by various criteria ranges between $6.5 \%$ and $10.1 \%$, and community prevalence of $4 \%$ is found in North India. Those attending gastroenterology clinics represent only the tip of the iceberg. The disorder substantially impairs the quality of life, and the overall health-care costs are high. IBS has therefore gained increased attention from clinicians, researchers, and pharmaceutical industries. It is often frustrating to both patients and physicians as the disease is usually chronic in nature and difficult to treat. However, the understanding of IBS has been changing from time to time and still most of its concepts are unknown. In this review we have discussed, debated, and synthesized the evidence base, focusing on underlying mechanisms in the brain and bowel. We conclude that it is both brain and bowel mechanisms that are responsible. The clinical implication of such mechanisms is discussed.
\end{abstract}

Key words: Bowel, brain, irritable bowel syndrome, mechanism, psychological

\section{Introduction}

Irritable bowel syndrome (IBS) has been recognized as one of the most common and best studied disorder among the group of functional gastrointestinal disorders. ${ }^{[1]}$ It is a functional bowel disorder in which abdominal pain or discomfort is associated with defecation or a change in bowel habit. ${ }^{[2]}$ In the Western world, IBS appears to affect up to $20 \%$ of the population at any given time, although the prevalence figures vary substantially depending on the definition of IBS. ${ }^{[3]}$ On the contrary in Asian countries, the median value of IBS prevalence defined by various criteria ranges $6.5-10.1 \% .^{[4]}$

\section{Address for correspondence:}

Dr. Susanta Kumar Padhy, Department of Psychiatry,

Postgraduate Institute of Medical Education and Research,

Sector 12, Chandigarh - 160 012, India.

E-mail: susanta.pgi30@yahoo.in

\begin{tabular}{|l|l|}
\hline \multicolumn{2}{|c|}{ Access this article online } \\
\hline Quick Response Code: & Website: \\
\hline & www.ruralneuropractice.com \\
\cline { 2 - 2 } & \\
\hline$\square$ & DOI: \\
\hline
\end{tabular}

In India, IBS has been reported to be common. ${ }^{[5]} \mathrm{A}$ recent study has estimated IBS prevalence in Northern India community to be $4 \% .{ }^{[6]}$ Though its exact incidence is hard to assess, but it appears that those attending gastroenterology clinics represent only the tip of the iceberg. ${ }^{[7]}$

The disorder substantially impairs the quality of life, and the overall health-care costs are high. IBS has therefore gained increased attention from clinicians, researchers, and pharmaceutical industries. It is often frustrating to both patients and physicians as the disease is usually chronic in nature and difficult to treat. However, the understanding of IBS has been changing from time to time and still most of its concepts are unknown. In this review we tend to find out the various etiological mechanisms underlying IBS.

This is an open access article distributed under the terms of the Creative Commons Attribution-NonCommercial-ShareAlike 3.0 License, which allows others to remix, tweak, and build upon the work non-commercially, as long as the author is credited and the new creations are licensed under the identical terms.

For reprints contact: reprints@medknow.com

How to cite this article: Padhy SK, Sahoo S, Mahajan S, Sinha SK. Irritable bowel syndrome: Is it "irritable brain" or "irritable bowel"? J Neurosci Rural Pract 2015;6:568-77. 


\section{Etiological Dilemmas: Is it Irritable "Bowel" or "Brain/Mind"?}

Studies on the pathophysiologic mechanisms behind IBS have always led to controversies that whether the predominant pathology lies in the bowel or in the brain. We provide here a brief overview of all such mechanisms studied so far in favor of both bowel and brain.

\section{Evidences in favor of irritable "bowel"}

If we look into the evolution of mechanistic hypothesis in IBS, then we can formulate that initially it was thought that abnormal colonic motility was the basic pathophysiologic mechanism behind IBS. But over the years, the concept has changed. Some of the mechanisms are listed below:

1. Abnormal motility

2. Visceral hypersensitivity

3. Role of infection

4. Role of inflammation

5. Role of bacterial overgrowth

6. Role of serotonin

7. Role of brain-gut axis interaction.

\section{Abnormal motility}

Evidences from manometric, electromyographic, and colonic transit studies (1980s) have demonstrated that patients with IBS have: (1) Discrete clustered contractions in the small intestine which are associated with episodes of abdominal pain, (2) abnormalities in the migratory motor complex, which may lead to either delayed (constipation) or accelerated (diarrhea) intestinal transit, and (3) very high amplitude propagating contractions within the colon, especially in the postprandial period which are associated with episodes of abdominal pain. ${ }^{[7-9]}$

Some of the studies which have tried to find out different types of altered motility in different parts of the gastrointestinal (GI) system are enlisted in Table 1.

However, no single pattern of disordered motility is pathognomonic of IBS. In general, the alterations in GI motility found in patients with IBS likely reflect an exaggeration of normal patterns of GI motility.

\section{Visceral hypersensitivity}

It has been proved by the use of technique of intraluminal balloon distension that patients with IBS have altered thresholds to pain within the GI tract, compared with non-IBS patients. IBS patients perceive balloon distension at much lower levels of inflation and describe the distension as more painful, compared with normal patients. ${ }^{[27-29]}$ They may also misinterpret normal GI function as painful.

Visceral hypersensitivity is a common and predominant pathophysiologic mechanism, responsible for triggering the motility disturbances and abdominal pain. Many researchers have proposed that it may be regarded as a "biological marker" of IBS. Nevertheless, only $60 \%$ of patients are hypersensitive to distension that is, mainly the diarrhea subtype (IBS-D) are more hypersensitive to rectal distension than patients who have constipation subtype (IBS-C). ${ }^{[30,31]}$

Although hypersensitivity is a frequent finding in patients with IBS, it does not appear to be a consistent indicator of IBS. Several external and internal factors can modulate visceral sensitivity. So, it cannot be used as a diagnostic marker for IBS. It seems to result from the sensitization of nerve afferent pathways originating from the GI tract.

\section{Role of infection}

Chaudhry and Truelove (1962) reported that a percentage of patients with irritable colon developed typical IBS symptoms after an acute infective enteritis. Epidemiologic studies have shown that GI infection is the strongest environmental risk factor for the development of IBS. ${ }^{[32]}$ A recent systematic review and meta-analysis identified that the pooled incidence for IBS development after infectious gastroenteritis was $10 \% .{ }^{[33]}$ Salmonella, Shigella, and Campylobacter are among the most frequently isolated infectious agents, but viral infection has also been documented as a trigger of IBS. ${ }^{[34,35]}$ Several risk factors increase the risk of postinfectious IBS (PI-IBS) development, including prolonged duration of the initial illness, toxicity of infecting bacterial strain, smoking, degree of mucosal inflammation, female gender, presence of psychological disorders, such as depression and anxiety, and treatment with antibiotics during the acute gastroenteritis episode. ${ }^{[36-38]}$ Studies showed a continuing presence of CD3 and CD8 T lymphocytes and increased expression of interleukin-1 (IL) beta in patients progressing to PI-IBS after acute infection with Shigella or Campylobacter jejuni. ${ }^{[39]}$

Though there is growing evidence in favour of infection as an etiologic model for IBS, but the point against it is that neither all patients have history of infection prior to developing IBS symptoms nor treatment by antibiotics helps in improvement of symptoms in all IBS patients.

\section{Role of mucosal inflammation}

Normal intestine is always in a state of inflammation, with a balance between commensal enteric organisms 
Table 1: Studies summarizing motility studies

\begin{tabular}{|c|c|c|}
\hline Author (year) & Part of GI system & Findings \\
\hline Van Wijk et al., $1992^{[10]}$ & \multirow[t]{4}{*}{ Stomach } & Delayed gastric emptying \\
\hline Evans et al., $1997^{[11]}$ & & Anger inhibits antral motility \\
\hline Welgan et al., 2000 & & Abnormalities detected in electrogastrogram in $25 \%$ of IBS \\
\hline Leahy et al., $1999^{[13]}$ & & patients with comorbid dyspepsia but in only $8 \%$ without dyspepsia \\
\hline Kumar and Wingate, $1985^{[14]}$ & \multirow[t]{4}{*}{ Small intestine (DCCs) } & Increased frequency and duration of DCCs and DCCs associated \\
\hline Kellow et al., 1990[15] & & \\
\hline Schmidt et al., 1996[16] & & Increased DCCs following CRH \\
\hline Fukudo et al., 1998 & & \\
\hline Kellow et al., $1988^{[18]}$ & \multirow{2}{*}{$\begin{array}{l}\text { Small intestine } \\
\text { (MMC and phasic contractions) }\end{array}$} & Increased frequency of MMCs \\
\hline Kellow et al., $1992^{[19]}$ & & Duodenal and jejunal contractions suppressed by stress \\
\hline Cann et al., $1983^{[20]}$ & \multirow[t]{3}{*}{ Small intestine (small bowel transit) } & Delayed in IBS-C and accelerated in IBS-D \\
\hline Lu et al., 1998[21] & & \\
\hline Vassallo et al., $1992^{[9]}$ & & \\
\hline Rogers et al., 1989[22] & \multirow[t]{3}{*}{ Colon and rectum (phasic contractions) } & Greater increase in phasic contractions after meal \\
\hline Welgan et al., 1988; ${ }^{[23]}$ & & Greater increase with stress \\
\hline Fukudo and Suzuki, $1987^{[24]}$ & & \\
\hline Bueno et al., $1980^{[25]}$ & Colon and rectum (myoelectric activity) & $\begin{array}{l}\text { Increased long spike bursts with diarrhea and irregular short spike } \\
\text { bursts with constipation }\end{array}$ \\
\hline Horikawa et al., 1999[26] & Colon (colonic transit) & Delayed in IBS-C and accelerated in IBS-D \\
\hline
\end{tabular}
DCCs: Discrete clustered contractions, CRH: Cortisol releasing hormone, MMC: Migratory motor complex, Gl: Gastrointestinal

and the immune system. Mast cells play a critical role in normal immune function and respond to antigen stimuli through degranulation resulting in release of the inflammatory mediators histamine and tryptase. Degree of cellularity of mucosal mast cells and proximity to sensory nerves have been found to be correlated with abdominal pain in IBS. ${ }^{[0]}$ Studies have reported that increased number of mast cells throughout the GI tract in patients with IBS with no history of gastroenteritis. ${ }^{[41]}$ It has also been seen that biopsy specimens contained increased numbers of neutrophils and mast cells in the colonic mucosa, and chronic inflammatory infiltrate with neuronal degeneration in the myenteric plexus of the jejunum. ${ }^{[42,43]}$

These findings have resulted in interest not only in the role of mast cells in IBS, but also the potential therapeutic role of mast cell stabilizers in IBS. However, the results are arbitrary with no consistent findings.

\section{Role of bacterial overgrowth}

Numerous theories have been implicated regarding the role of small intestinal bacterial overgrowth (SIBO) in the pathogenesis of IBS, however definite evidence is still lacking. SIBO has been defined based on jejunal aspirate and culture demonstrating more than $10^{5} \mathrm{CFU} / \mathrm{mL}$ of coliform bacteria in the small intestine. ${ }^{[44]}$ Methodological issues in diagnosing SIBO by lactulose breath test or by glucose breath test has resulted in controversies.
However, factors which support role of bacteria in IBS are: ${ }^{[45]}$

- Excessive fermentation

- Increased small bowel gas formation

- Abnormal breath tests compared with healthy controls

- Excessive coliform bacteria in proximal small bowel of IBS subjects

- Improvement of IBS symptoms with antibiotic therapy.

The causal link of SIBO with IBS is somewhat argued due to the evidence of treatment of SIBO with nonabsorbable antibiotics like rifaximin which has been shown to result in improvement of symptoms in patients with IBS. But still, it remains yet to be clarified whether SIBO is an essential factor in the pathophysiology of IBS, or is just linked by serendipity.

\section{Role of serotonin}

Serotonin (5-hydroxytryptamine $[5-\mathrm{HT}]$ ) is a neurotransmitter vital to normal GI function. Studies have shown that 5-HT plays a critical role in GI motility, visceral sensitivity, GI immune function, and blood flow. ${ }^{[46]}$ At the molecular level, abnormalities in the serotonin reuptake transport system have been found in IBS patients. Polymorphism of the 5-HT2A receptor gene may be associated with the development of IBS ${ }^{[47]}$ has also been suggested. In a recent study done in India, a significant association was found between 
the SS genotype of serotonin re-uptake transporter polymorphism (SERT-P) and constipation predominant type of IBS. ${ }^{[48]}$

Serotonin released as neurotransmitter from both the afferent and efferent neurons of the myenteric plexus present in layers of intestinal wall increases intestinal motility and secretion by increasing the firing rate of secretomotor neurons. These secretions from the crypts of Lieberkuhn in turn induce vasodilation of arterioles to increase blood flow in support to stimulated secretion. In case of IBS patients with predominant diarrhea subtype, there is increased serotonin production leading to increase in secretions. Thus, serotonin plays a major role in the pathophysiology of IBS-D type. Evidence in favour of this mechanism can be linked to the efficacy of the 5-HT3 receptor antagonist (Alosetron) blockade in women with diarrhea predominant IBS which suggests an overstimulation of secretomotor neurons by serotonin. ${ }^{[4,50]}$

It has also been investigated and found that in patients with constipation predominant IBS there occurs an increased serotonin concentration in colonic mucosa when compared with individuals with diarrhea predominant IBS, reflecting impaired release of serotonin. ${ }^{[51]}$ This further strengthens the role of serotonin in IBS.

\section{Brain - gut axis interactions in irritable bowel syndrome}

"Brain-gut axis" refers to the bi-directional continuous communication between the gut (enteric nervous system [ENS], luminal wall) and the central nervous system (CNS), including the hypothalamic-pituitary-adrenal axis (HPA). It plays a prominent role in modulation of gut function in health and disease.

The emotional motor system (EMS) in the brain - a revised name for limbic system and some paralimbic structures (including the medial prefrontal cortex, amygdala, and hypothalamus) communicate emotional changes via the autonomic nervous system to the gut. The ENS, also called the "brain-in-the-gut," organizes and coordinates activity of musculature, mucosal epithelium, and vasculature to generate functionally significant patterns of behavior. ${ }^{[52,53]}$

Pathophysiological consequences of disruption of brain-gut axis has been linked to many disorders of GI tract like gastroesophageal reflux disease, peptic ulcers, functional dyspepsia, IBS, inflammatory bowel disease, food allergy etc. ${ }^{[54,55]}$

In IBS, it is hypothesized that stress acts on the emotional limbic system and leads to increased release of adrenocorticotropic hormone and cortisol which act upon the ENS causing the symptoms of IBS that is, abdominal pain, loose stools etc. There is also a role of several immune mediators like IL-6, IL-8 etc.

Evidence in this favor are from the various neuroimaging studies (positron emission tomography, functional magnetic resonance imaging) on IBS patients which have suggested that there is a dysregulation of central and ENS which induces dysmotility or visceral sensitivity and all these processes are modified by psychosocial processes. ${ }^{[56,57]}$

However, still many of these mechanisms are yet to be understood and mechanisms related to bowel to be the only pathophysiology of IBS is still debatable.

Now let us discuss the various evidences and mechanisms which favor that brain and the psyche has a predominant role in the pathophysiology of IBS.

\section{Evidences in Favor of "Irritable Brain and/or Mind"}

For better understanding, let us conceptualize the bio-psycho-social model of IBS which includes

- Biological factors: Neuroanatomical factors, neuroimmunological factors

- Role of psyche

- Social factors: Environmental influences and role of stress.

\section{Biological factors \\ Neuroanatomical factors}

As discussed above, the EMS is concerned with the modulation at CNS level. In IBS patients, it has been seen that there is selective activation of dorsal cingulate cortex which is concerned with attentional processes and response selection. Activation of dorsolateral prefrontal cortex concerned with emotional and autonomic response to stimuli has also been seen. IBS patients showed greater degree of activation in these regions than controls. ${ }^{[58]}$

Several studies have been carried out to unpin the details of brain pathways behind IBS, but still whether it is selective attention at cortical level or there is increased afferent processing of the pathways ascending to brain remains unclear.

\section{Neurophysiological factors}

CNS communicates with ENS via three pathways that is, autonomic pathway, neural pathway, and neuroendocrine pathway. 
As far as autonomic pathway is concerned, data from various studies have not been consistent. Some studies have suggested that sympathetic activity may be increased or reduced ${ }^{[59]}$ while some other studies have suggested diminished or enhanced parasympathetic tone. ${ }^{[60,61]}$ Overall it has been observed that patients with IBS have altered autonomic activity associated with symptom exacerbation.

Neural pathways play a major role in modulating symptoms of IBS especially the experience of pain. Spinothalamic tracts provide information that is largely directed to the primary somatosensory cortex and functions to localize and discriminate visceral stimuli. Spinoreticular pathways do not function primarily to localize stimuli but are important in the reflexive, affective, and motivational aspects of sensation. The brain modulates afferent pain signals by dispersing inhibitory signals to the spinal cord. The inhibitory efferent signals then travel by way of the opioidergic, serotoninergic, and noradrenergic systems to the dorsal horn of the spinal cord where they presynaptically inhibit the afferent pain signals.

It was seen in studies that the dorsal subregion of the anterior cingulate cortex is an area that is selectively activated to a greater degree in patients with IBS compared with controls. ${ }^{[56,62]}$ Evidence in this regard is seen in the effectiveness of tricyclic antidepressants in pain relief, at doses less than that used in depression. ${ }^{[63-65]}$ Brain imaging studies have shown compromised activation of corticopontine pain inhibitory circuits. Patients with IBS may fail to use CNS downregulating mechanisms in response to incoming or anticipated visceral pain. ${ }^{[6]}$ It seems that differences exist between patients with IBS and healthy subjects with respect to regional brain activation. But, debate still continues whether it is the central activation or the peripheral pathways responsible for pathogenesis.

If we consider the neuroendocrine pathways abnormalities, alteration in the HPA has been reported in IBS patients. Studies have reported an increased level of corticotropin releasing hormone which in turn affects the motility and sensitivity of the gut. ${ }^{[67]}$ However, it is unsure whether the change is primary or in response to other stressors. Studies have reported that increased levels of cortisol in IBS patients compared to controls, either at baseline or in response to stress. ${ }^{[68]}$

\section{Role of the psyche}

There is upcoming evidence between the relationship of IBS and "the psyche." Psychiatric disorders have been found to coexist with IBS patients as evident from various studies. Human psyche is affected by several factors like personality factors, altered health beliefs, and coping skills.

\section{Psychiatric disorders and irritable bowel syndrome}

Several studies show that among patients who seek medical attention for IBS, around 70\% have psychiatric comorbidity. ${ }^{[69-71]}$ Rates of psychiatric disorders are depression $-46 \%$, generalized anxiety disorder $-34 \%$, panic disorder $-31 \%$, and somatization - $26 \% .{ }^{[72]}$ Psychiatric disturbances among persons with IBS may represent a reaction to stress of chronic GI illness. ${ }^{[73,74]}$ Severity of anxiety and depressive symptoms correlated with IBS symptoms. ${ }^{[75]}$ Patients with co-morbid anxiety had more pronounced cortical evoked potential indicating selective attention compared with noncomorbid IBS. ${ }^{[76]}$ Also it has been reported that the prevalence and role of psychiatric comorbidity in individuals with IBS is higher than in nonulcer dyspepsia. ${ }^{[7]}$

It has also been seen that psychiatric disorders and IBS share common genetic predisposition. For example, SERT-P gene is associated with a subtype of IBS and the same polymorphism in promoter region of SERT gene is also seen in depression. ${ }^{[78,79]}$ Another study has reported that $\mathrm{C} / \mathrm{C}$ genotype polymorphism in 5HT3A receptors is associated with increased anxiety and severity of IBS symptoms. ${ }^{[79,80]}$ A positive association between psychological stress and abnormal immunity has been implicated as evident from a study in which it was seen that IBS patients with high level of IL-6 was associated with the presence of psychological co-morbidity. ${ }^{[81]}$

In summary, still there is little data to support the etiological role for psychiatric disturbance in IBS. However, it has significant impact on severity as well as outcome. Treatment of psychiatric disturbances can result in improvement of symptoms. Hence, it is important to recognize and treat them.

\section{Personality factors}

Majority of studies have supported that IBS patients have high level of neuroticism. ${ }^{[82]}$ Neuroticism might influence coping strategies like catastrophizing and somatization. ${ }^{[83]}$ Neuroticism is also a significant predictor of illness perception and treatment beliefs in IBS. ${ }^{[84]}$ Several studies have found that many IBS sufferers score high in the personality trait alexithymia ${ }^{[85,86]}$ which is associated with increased symptom severity in IBS. However, these personality traits are not unique to IBS, but it reflects an important intervening variable.

\section{Health beliefs and coping skills}

Patients having IBS often believe that their chronic gut symptoms indicate a serious illness. They report a sense 
of losing freedom, spontaneity, social contacts and feeling of fearfulness, shame and embarrassment. ${ }^{[87]}$ These in turn lead to change in their behavior like avoidance of activities and adaptations in routine in an effort to gain control. ${ }^{[88]}$

Patients with IBS have high scores on bodily preoccupation, hypochondriacal beliefs and disease phobia. ${ }^{[89]}$ They are more likely to catastrophize than patients with organic disorder. It has been noticed that patients with IBS with a high degree of catastrophizing, have a tendency to report more severe pain. ${ }^{[90]}$

It is difficult to draw conclusions in generalizing coping skills in patients with IBS. Health beliefs are irrational leading to hypochondriacal attitudes and various maladaptive coping strategies such as catastrophizing are used.

\section{Role of social factors}

\section{Role of social learning}

Social learning has been implicated as one of the important social factors in the biopsychosocial model of IBS. Many patients with moderate to severe IBS have a coexisting somatization disorder, and it is quite likely that excessive illness behavior could be transmitted from parents to children in an intergenerational transmission of illness behavior. ${ }^{[91]}$ Parental modeling and reinforcement of illness behavior contributes to the causes of illness. It has been suggested that contribution of social learning is as great as the contribution of heredity.

\section{Environmental stressors}

Environmental stressors have been classified as early life stressors and psychosocial stressors. Some of these factors implicated in IBS are as described below:

Early life stressors like prenatal traumatic events (poor nutrition in fetal life), early stressful life events (surgery, emotional, physical or sexual abuse), family dysfunctioning (divorce of parents), family history of abdominal pain, bowel dysfunction, and inflammatory bowel diseases. ${ }^{[87]}$

Psychosocial stressors like major life events (divorce, unemployment, death of a relative), major social events (social changes, revolution), and daily hassles.

Abuse history either in childhood or during adult life needs a special mention in this aspect. Abuse has been reported by patients with other chronic and painful non-GI functional conditions as well. ${ }^{[92]}$ But the constant finding is that abused individuals experience high level of psychological distress and somatization, both being risk factors for development of IBS. ${ }^{[93]}$ Two recent studies have concluded that lifetime history of broad range of trauma and abuse are independent risk factors for development of IBS. ${ }^{[9,95]}$ The findings suggest that physicians should become aware of various risk factors among patients with chronic or severe refractory symptoms and some sort of psychological treatment is necessary for such patients.

\section{Role of stress}

Stress is defined as acute threat to the homeostasis of an organism, real (physical) or perceived (psychological), and posed by events in the outside world or from within. ${ }^{\left[{ }^{[9]}\right.}$ In the genetically predisposed individual, both early life stress and severe life threatening stress referred to as pathological stress can result in permanent irreversible enhancement of responsiveness of central stress circuits and vulnerability to development of functional disorders later in life. Later on, fear conditioning plays an important role in triggering stress responses to situations and context.

In IBS patients, it has been reported from many studies that stress is associated with symptom severity. ${ }^{[97]}$ Nearly $51 \%$ of IBS patients report that a stressful event preceded the onset of the disorder. ${ }^{[98]}$ Patients with IBS have greater reactivity to stress. The identification of a specific stressor helps in planning treatment through psychological and pharmacological treatment.

A recent study which aimed to investigate the effect of stress on intestinal permeability in humans revealed that when the subjects were subjected to acute psychological stress there was increase in small intestinal permeability. ${ }^{[99]}$ Also when the link between posttraumatic stress disorder and IBS was investigated in an urban African Americans population, the former was found to be independently associated with IBS, thereby further strengthening the role of psychosocial stress in IBS. ${ }^{[100]}$

Acute psychological stress, as well as administration of corticoliberin (also known as corticotrophin releasing factor) to mimic the stress response, have both been found to increase intestinal mucosal permeability in healthy volunteers. ${ }^{[99]}$ It is also well known that stress affects the immune system. ${ }^{[54]} \mathrm{A}$ number of studies have supported that the increase in intestinal permeability in patients with IBS is linked to enhanced activity of the immune system via release of proinflammatory cytokines such as tumor necrosis factor and interferon-gamma. ${ }^{101,102]}$

Some landmark studies that have evaluated the role of stress in IBS are described in Table 2. 
Table 2: Studies evaluating the role of stress in IBS

\begin{tabular}{|c|c|c|c|}
\hline Study (year) & $\begin{array}{l}\text { Number of patients of } \\
\text { different categories }\end{array}$ & $\begin{array}{l}\text { Scale used/assessment } \\
\text { technique }\end{array}$ & Findings and remarks \\
\hline \multirow{3}{*}{$\begin{array}{l}\text { Mendeloff } \\
\text { et al., 1970[103] }\end{array}$} & 102 IBS & \multirow[t]{3}{*}{ Unvalidated stress interview } & \multirow[t]{3}{*}{ Stress in IBS $>\mathrm{UC}$ or controls } \\
\hline & $158 \cup C$ & & \\
\hline & 735 controls & & \\
\hline \multirow{3}{*}{$\begin{array}{l}\text { Fava and } \\
\text { Pavan, } \\
1976^{[104]}\end{array}$} & 20 IBS & \multirow{3}{*}{$\begin{array}{l}\text { Standardized life event } \\
\text { scale }\end{array}$} & \multirow{3}{*}{$\begin{array}{l}\text { Stressful life events reported in IBS patients }>\text { IBD or appendicitis } \\
\text { patients }\end{array}$} \\
\hline & 20 IBD & & \\
\hline & 20 appendicitis & & \\
\hline \multirow{2}{*}{$\begin{array}{l}\text { Drossman } \\
\text { et al., } 1982^{[105]}\end{array}$} & 135 IBS & \multirow[t]{2}{*}{ Interview-self-report } & \multirow{2}{*}{$\begin{array}{l}72.6 \% \text { patients with IBS reported stress led to change in stool pattern } \\
\text { and } 84.4 \% \text { patients with IBS reported stress led to abdominal pain }\end{array}$} \\
\hline & 654 controls & & \\
\hline \multirow{3}{*}{$\begin{array}{l}\text { Drossman } \\
\text { et al., } 1988^{[106]}\end{array}$} & 72 IBS consulters & \multirow{3}{*}{$\begin{array}{l}\text { Standardized life event } \\
\text { scale }\end{array}$} & \multirow{2}{*}{$\begin{array}{l}\text { IBS consulters reported fewer stressful life events and perceive them } \\
\text { as less severe than IBS nonconsulters and controls }\end{array}$} \\
\hline & 82 IBS nonconsulters & & \\
\hline & 84 controls & & $\begin{array}{l}\text { Remarks: Treatment seeking IBS patients have improvement in } \\
\text { perception of stress and have less stressful life events }\end{array}$ \\
\hline \multirow{3}{*}{$\begin{array}{l}\text { Creed } \\
\text { et al., } 1988^{[107]}\end{array}$} & 79 functional Gl patients & \multirow{3}{*}{$\begin{array}{l}\text { Psychiatric interview based } \\
\text { on life events and difficulty } \\
\text { schedule }\end{array}$} & $60-66 \%$ patients with functional GI disorders reported severe life \\
\hline & 56 organic Gl patients & & \\
\hline & 135 controls & & Remarks: Stress life events have definite role behind onset of IBS \\
\hline \multirow{3}{*}{$\begin{array}{l}\text { Dinan } \\
\text { et al., } 1991^{[108]}\end{array}$} & 40 IBS & \multirow[t]{3}{*}{ Psychosocial assessment } & IBS patients reported greater negative life events and scored higher \\
\hline & 32 peptic ulcer patients & & $\begin{array}{l}\text { on neuroticism and extroversion than patients with peptic ulcer who did } \\
\text { not have any psychiatric diagnosis but were similar in above aspects } \\
\text { when compared with peptic ulcer patients with psychiatric diagnosis }\end{array}$ \\
\hline & & & $\begin{array}{l}\text { Remarks: Stress and personality traits of neuroticism and extroversion } \\
\text { has been associated strongly with in both IBS and peptic ulcer with } \\
\text { psychiatric comorbidity }\end{array}$ \\
\hline \multirow{3}{*}{$\begin{array}{l}\text { Whitehead } \\
\text { et al., } 1992^{[98]}\end{array}$} & 39 IBS & \multirow{3}{*}{$\begin{array}{l}\text { Life event questionnaire } \\
\text { given every } 3 \text { months for } \\
1 \text {-year }\end{array}$} & Stressful life events in IBS >FBD \\
\hline & 108 FBD & & $\begin{array}{l}\text { Stress correlated with number of bowel symptoms, disability days, } \\
\text { and physician visits }\end{array}$ \\
\hline & & & IBS and FBD patients showed greater reactivity to stress than controls \\
\hline \multirow{3}{*}{$\begin{array}{l}\text { Levy } \\
\text { et al., 1997[109] }\end{array}$} & 26 IBS patients & \multirow{3}{*}{$\begin{array}{l}\text { Evaluated relationship } \\
\text { between daily stress using } \\
\text { and GI symptoms using daily } \\
\text { diaries and life event survey }\end{array}$} & \multirow{2}{*}{$\begin{array}{l}\text { Mean GI symptoms and stress in IBS patients > IBS nonpatients } \\
>\text { controls }\end{array}$} \\
\hline & 23 IBS nonpatients & & \\
\hline & 26 controls & & $\begin{array}{l}\text { Both IBS patients and nonpatients had significantly positive } \\
\text { relationship between daily stressors and daily symptoms }\end{array}$ \\
\hline
\end{tabular}

IBD: Inflammatory bowel disease, UC: Ulcerative colitis, Gl: Gastrointestinal, FBD: Functional bowel disorder, IBS: Irritable bowel syndrome

Summarizing all the psychosocial factors, we can say that direct cause and effect relationship has not been found. Various psychological factors have an effect on outcome as well as they are associated with each other. Each one of the factor plays an important role as far as management is concerned and all these should be kept in the management protocol while managing an IBS patient.

Lastly, we summarize, the etiopathogenesis in IBS in Table 3.

Mostly the evidence has been found on these above mentioned aspects/areas of research. There have always been controversies in almost all the theories put forward to explain IBS. We can rather say that it is the "irritable" brain-gut axis which plays a significant role in the genesis of IBS.

\section{Conclusions and Future Directions}

Our understanding of the pathophysiology of IBS is still in its evolution level. Psychosocial factors contribute
Table 3: Summary of etiopathogenesis of IBS

\begin{tabular}{ll}
\hline Irritable bowel & Irritable brain/mind \\
\hline Visceral hypersensitivity & "Irritable" CNS \\
Altered motility & "Irritable" ANS \\
Inflammation in bowel (PI-IBS) & "Irritable" mind \\
Immune activation (cytokines) & Psychiatric disorders \\
& Psychosocial stress \\
\hline PI-IBS: Postinfectious irritable bowel syndrome, CNS: Central nervous system, \\
ANS: Autonomic nervous system
\end{tabular}

to predisposition, precipitation, and perpetuation of IBS symptoms. Neuroimaging studies have tried to delineate the relationship between psychosocial factors and emotions, gut physiology and clinical symptoms.

Screening subjects for psychosocial stressors may be an effective intervention strategy. The potential role that inflammation may play in IBS, genes involved in cytokine production and/or receptors is an important avenue for future research.

Evidence is growing that IBS can no longer be purely regarded as a functional disorder. Neither of the notions, 
about IBS that, "It's all in the head" or "it's all in the mind", is right, in its entirety. Rather, psychiatrists and physicians/gastroenterologists should work in close liaison and manage it comprehensively. Essentially, it is the person as well as the GI symptoms to be taken care of, along with attempts to improve the quality of life as well. Therefore, perhaps, it is the combination of irritable "brain" and "bowel" is what constitutes the disease entity.

\section{Financial support and sponsorship Nil.}

\section{Conflicts of interest}

There are no conflicts of interest.

\section{References}

1. Drossman DA. The functional gastrointestinal disorders and the Rome III process. Gastroenterology 2006;130:1377-90.

2. World Gastroenterology Organization (WGO). World Gastroenterology Organization Global Guideline: Irritable Bowel Syndrome: A Global Perspective. Munich (Germany): World Gastroenterology Organization (WGO); 2009. p. 20.

3. Thompson WG, Heaton KW, Smyth GT, Smyth C. Irritable bowel syndrome in general practice: Prevalence, characteristics, and referral. Gut 2000;46:78-82.

4. Chang FY, Lu CL, Chen TS. The current prevalence of irritable bowel syndrome in Asia. J Neurogastroenterol Motil 2010;16:389-400.

5. Kotwal MR, Durrani HA, Shah SN. Chronic colonic diarrhoea in North-West India. (A clinical study with special reference to the syndrome of irritable colon). J Indian Med Assoc 1978;70:77-80.

6. Makharia GK, Verma AK, Amarchand R, Goswami A, Singh P, Agnihotri A, et al. Prevalence of irritable bowel syndrome: A community based study from northern India. J Neurogastroenterol Motil 2011;17:82-7.

7. Kellow JE, Eckersley GM, Jones M. Enteric and central contributions to intestinal dysmotility in irritable bowel syndrome. Dig Dis Sci 1992;37:168-74.

8. Snape WJ Jr, Carlson GM, Matarazzo SA, Cohen S. Evidence that abnormal myoelectrical activity produces colonic motor dysfunction in the irritable bowel syndrome. Gastroenterology 1977;72:383-7.

9. Vassallo MJ, Camilleri M, Phillips SF, Steadman CJ, Talley NJ, Hanson RB, et al. Colonic tone and motility in patients with irritable bowel syndrome. Mayo Clin Proc 1992;67:725-31.

10. van Wijk HJ, Smout AJ, Akkermans LM, Roelofs JM, ten Thije OJ. Gastric emptying and dyspeptic symptoms in the irritable bowel syndrome. Scand J Gastroenterol 1992;27:99-102.

11. Evans PR, Bak YT, Shuter B, Hoschl R, Kellow JE. Gastroparesis and small bowel dysmotility in irritable bowel syndrome. Dig Dis Sci 1997;42:2087-93

12. Welgan $\mathrm{P}$, Meshkinpour $\mathrm{H}, \mathrm{Ma}$ L. Role of anger in antral motor activity in irritable bowel syndrome. Dig Dis Sci 2000;45:248-51.

13. Leahy A, Besherdas K, Clayman C, Mason I, Epstein O. Abnormalities of the electrogastrogram in functional gastrointestinal disorders. Am J Gastroenterol 1999;94:1023-8.

14. Kumar D, Wingate DL. The irritable bowel syndrome: A paroxysmal motor disorder. Lancet 1985;2:973-7.

15. Kellow JE, Gill RC, Wingate DL. Prolonged ambulant recordings of small bowel motility demonstrate abnormalities in the irritable bowel syndrome. Gastroenterology 1990;98(5 Pt 1):1208-18.

16. Schmidt T, Hackelsberger N, Widmer R, Meisel C, Pfeiffer A, Kaess H. Ambulatory 24-hour jejunal motility in diarrhea-predominant irritable bowel syndrome. Scand J Gastroenterol 1996;31:581-9.
17. Fukudo S, Nomura T, Hongo M. Impact of corticotropin-releasing hormone on gastrointestinal motility and adrenocorticotropic hormone in normal controls and patients with irritable bowel syndrome. Gut 1998;42:845-9.

18. Kellow JE, Phillips SF, Miller LJ, Zinsmeister AR. Dysmotility of the small intestine in irritable bowel syndrome. Gut 1988;29:1236-43.

19. Kellow JE, Langeluddecke PM, Eckersley GM, Jones MP, Tennant CC. Effects of acute psychologic stress on small-intestinal motility in health and the irritable bowel syndrome. Scand J Gastroenterol 1992;27:53-8.

20. Cann PA, Read NW, Brown C, Hobson N, Holdsworth CD. Irritable bowel syndrome: Relationship of disorders in the transit of a single solid meal to symptom patterns. Gut 1983;24:405-11.

21. Lu CL, Chen CY, Chang FY, Lee SD. Characteristics of small bowel motility in patients with irritable bowel syndrome and normal humans: An oriental study. Clin Sci (Lond) 1998;95:165-9.

22. Rogers J, Henry MM, Misiewicz JJ. Increased segmental activity and intraluminal pressures in the sigmoid colon of patients with the irritable bowel syndrome. Gut 1989;30:634-41.

23. Welgan $\mathrm{P}$, Meshkinpour $\mathrm{H}$, Beeler M. Effect of anger on colon motor and myoelectric activity in irritable bowel syndrome. Gastroenterology 1988;94(5 Pt 1):1150-6.

24. Fukudo S, Suzuki J. Colonic motility, autonomic function, and gastrointestinal hormones under psychological stress on irritable bowel syndrome. Tohoku J Exp Med 1987;151:373-85.

25. Bueno L, Fioramonti J, Ruckebusch Y, Frexinos J, Coulom P. Evaluation of colonic myoelectrical activity in health and functional disorders. Gut 1980;21:480-5.

26. Horikawa $\mathrm{Y}$, Mieno H, Inoue M, Kajiyama G. Gastrointestinal motility in patients with irritable bowel syndrome studied by using radiopaque markers. Scand J Gastroenterol 1999;34:1190-5.

27. Whitehead WE, Holtkotter B, Enck P, Hoelzl R, Holmes KD, Anthony J, et al. Tolerance for rectosigmoid distention in irritable bowel syndrome. Gastroenterology 1990;98(5 Pt 1):1187-92.

28. Munakata J, Naliboff B, Harraf F, Kodner A, Lembo T, Chang L, et al. Repetitive sigmoid stimulation induces rectal hyperalgesia in patients with irritable bowel syndrome. Gastroenterology 1997;112:55-63.

29. Schmulson M, Chang L, Naliboff B, Lee OY, Mayer EA. Correlation of symptom criteria with perception thresholds during rectosigmoid distension in irritable bowel syndrome patients. Am J Gastroenterol 2000;95:152-6.

30. Whitehead WE, Palsson OS. Is rectal pain sensitivity a biological marker for irritable bowel syndrome: Psychological influences on pain perception. Gastroenterology 1998;115:1263-71.

31. Delvaux M. Role of visceral sensitivity in the pathophysiology of irritable bowel syndrome. Gut 2002;51 Suppl 1:167-71.

32. Ruigómez A, García Rodríguez LA, Panés J. Risk of irritable bowel syndrome after an episode of bacterial gastroenteritis in general practice: Influence of comorbidities. Clin Gastroenterol Hepatol 2007;5:465-9.

33. Thabane M, Kottachchi DT, Marshall JK. Systematic review and meta-analysis: The incidence and prognosis of post-infectious irritable bowel syndrome. Aliment Pharmacol Ther 2007;26:535-44.

34. Spiller RC. Role of infection in irritable bowel syndrome. J Gastroenterol 2007:42 Suppl 17:41-7.

35. Neal KR, Hebden J, Spiller R. Prevalence of gastrointestinal symptoms six months after bacterial gastroenteritis and risk factors for development of the irritable bowel syndrome: Postal survey of patients. BMJ 1997;314:779-82.

36. Spiller R, Garsed K. Infection, inflammation, and the irritable bowel syndrome. Dig Liver Dis 2009;41:844-9.

37. Thabane M, Marshall JK. Post-infectious irritable bowel syndrome. World J Gastroenterol 2009;15:3591-6.

38. Barbara G, Cremon C, Pallotti F, De Giorgio R, Stanghellini V, Corinaldesi R. Postinfectious irritable bowel syndrome. J Pediatr Gastroenterol Nutr 2009;48 Suppl 2:S95-7.

39. Gwee KA, Collins SM, Read NW, Rajnakova A, Deng Y, Graham JC, et al. Increased rectal mucosal expression of interleukin 1 beta in recently acquired post-infectious irritable bowel syndrome. Gut 2003;52:523-6.

40. Barbara G, Stanghellini V, De Giorgio R, Cremon C, Cottrell GS, Santini $\mathrm{D}$, et al. Activated mast cells in proximity to colonic nerves correlate with abdominal pain in irritable bowel syndrome. Gastroenterology 2004;126:693-702. 
41. Chadwick VS, Chen W, Shu D, Paulus B, Bethwaite P, Tie A, et al. Activation of the mucosal immune system in irritable bowel syndrome. Gastroenterology 2002;122:1778-83.

42. Törnblom H, Lindberg G, Nyberg B, Veress B. Full-thickness biopsy of the jejunum reveals inflammation and enteric neuropathy in irritable bowel syndrome. Gastroenterology 2002;123:1972-9.

43. Guilarte M, Santos J, de Torres I, Alonso C, Vicario M, Ramos L, et al. Diarrhoea-predominant IBS patients show mast cell activation and hyperplasia in the jejunum. Gut 2007;56:203-9.

44. Khoshini R, Dai SC, Lezcano S, Pimentel M. A systematic review of diagnostic tests for small intestinal bacterial overgrowth. Dig Dis Sci 2008;53:1443-54.

45. Pimentel M, Park S, Mirocha J, Kane SV, Kong Y. The effect of a nonabsorbed oral antibiotic (rifaximin) on the symptoms of the irritable bowel syndrome: A randomized trial. Ann Intern Med 2006;145:557-63.

46. Kim DY, Camilleri M. Serotonin: A mediator of the brain-gut connection. Am J Gastroenterol 2000;95:2698-709.

47. Yeo A, Boyd P, Lumsden S, Saunders T, Handley A, Stubbins M, et al. Association between a functional polymorphism in the serotonin transporter gene and diarrhoea predominant irritable bowel syndrome in women. Gut 2004;53:1452-8.

48. Sikander A, Rana SV, Sinha SK, Prasad KK, Arora SK, Sharma SK, et al. Serotonin transporter promoter variant: Analysis in Indian IBS patients and control population. J Clin Gastroenterol 2009;43:957-61.

49. Houghton LA, Foster JM, Whorwell PJ. Alosetron, a 5-HT3 receptor antagonist, delays colonic transit in patients with irritable bowel syndrome and healthy volunteers. Aliment Pharmacol Ther 2000;14:775-82.

50. Camilleri M, Northcutt AR, Kong S, Dukes GE, McSorley D, Mangel AW. Efficacy and safety of alosetron in women with irritable bowel syndrome: A randomised, placebo-controlled trial. Lancet 2000;355:1035-40.

51. Miwa J, Echizen H, Matsueda K, Umeda N. Patients with constipation-predominant irritable bowel syndrome (IBS) may have elevated serotonin concentrations in colonic mucosa as compared with diarrhea-predominant patients and subjects with normal bowel habits. Digestion 2001;63:188-94.

52. Wood JD. Neuropathophysiology of irritable bowel syndrome. J Clin Gastroenterol 2002;35 1 Suppl: S11-22.

53. Mayer EA, Naliboff BD, Chang L. Basic pathophysiologic mechanisms in irritable bowel syndrome. Dig Dis 2001;19:212-8.

54. Vivinus-Nébot M, Dainese R, Anty R, Saint-Paul MC, Nano JL, Gonthier $\mathrm{N}$, et al. Combination of allergic factors can worsen diarrheic irritable bowel syndrome: Role of barrier defects and mast cells. Am J Gastroenterol 2012;107:75-81.

55. Cryan JF, O’Mahony SM. The microbiome-gut-brain axis: From bowel to behavior. Neurogastroenterol Motil 2011;23:187-92.

56. Mertz H, Morgan V, Tanner G, Pickens D, Price R, Shyr Y, et al. Regional cerebral activation in irritable bowel syndrome and control subjects with painful and nonpainful rectal distention. Gastroenterology 2000;118:842-8

57. Nakai A, Kumakura Y, Boivin M, Rosa P, Diksic M, D’Souza D, et al. Sex differences of brain serotonin synthesis in patients with irritable bowel syndrome using alpha-[11C] methyl-L-tryptophan, positron emission tomography and statistical parametric mapping. Can J Gastroenterol 2003;17:191-6.

58. Jones MP, Dilley JB, Drossman D, Crowell MD. Brain-gut connections in functional GI disorders: Anatomic and physiologic relationships. Neurogastroenterol Motil 2006;18:91-103.

59. Waring WS, Chui M, Japp A, Nicol EF, Ford MJ. Autonomic cardiovascular responses are impaired in women with irritable bowel syndrome. J Clin Gastroenterol 2004;38:658-63.

60. Lee CT, Chuang TY, Lu CL, Chen CY, Chang FY, Lee SD. Abnormal vagal cholinergic function and psychological behaviors in irritable bowel syndrome patients: A hospital-based oriental study. Dig Dis Sci 1998;43:1794-9.

61. Jarrett ME, Burr RL, Cain KC, Hertig V, Weisman P, Heitkemper MM. Anxiety and depression are related to autonomic nervous system function in women with irritable bowel syndrome. Dig Dis Sci 2003;48:386-94.

62. Naliboff BD, Derbyshire SW, Munakata J, Berman S, Mandelkern M, Chang L, et al. Cerebral activation in patients with irritable bowel syndrome and control subjects during rectosigmoid stimulation. Psychosom Med 2001;63:365-75.
63. Olden KW. Targeted therapies for diarrhea-predominant irritable bowel syndrome. Clin Exp Gastroenterol 2012;5:69-100.

64. Jackson JL, O’Malley PG, Tomkins G, Balden E, Santoro J, Kroenke K. Treatment of functional gastrointestinal disorders with antidepressant medications: A meta-analysis. Am J Med 2000;108:65-72.

65. Ford AC. Management of irritable bowel syndrome. Minerva Gastroenterol Dietol 2009;55:273-87.

66. Chang L, Harris LA. Pathophysiology of IBS and Serotonin Signaling. Medscape; 2004. Available from: http://www.medscape.org/viewarticle /463521_3. [Last accessed on 2015 Jul 25].

67. Patacchioli FR, Angelucci L, Dellerba G, Monnazzi P, Leri O. Actual stress, psychopathology and salivary cortisol levels in the irritable bowe syndrome (IBS). J Endocrinol Invest 2001;24:173-7.

68. Garakani A, Win T, Virk S, Gupta S, Kaplan D, Masand PS. Comorbidity of irritable bowel syndrome in psychiatric patients: A review. Am J Ther 2003;10:61-7.

69. Posserud I, Agerforz P, Ekman R, Björnsson ES, Abrahamsson H, Simrén M. Altered visceral perceptual and neuroendocrine response in patients with irritable bowel syndrome during mental stress. Gut 2004;53:1102-8.

70. Longstreth GF. Irritable bowel syndrome. In: Manu P, editor. Functional Somatic Syndrome. Cambridge: University Press; 1998. p. 55-73.

71. Lydiard RB. Irritable bowel syndrome, anxiety, and depression: What are the links? J Clin Psychiatry 2001;62 Suppl 8:38-45.

72. Farting MJ. Fortnightly review: Irritable bowel, irritable body, or irritable brain? BMJ 1995;310:171-5.

73. Walker EA, Gelfand AN, Gelfand MD, Katon WJ. Psychiatric diagnoses, sexual and physical victimization, and disability in patients with irritable bowel syndrome or inflammatory bowel disease. Psychol Med 1995;25:1259-67.

74. Kurina LM, Goldacre MJ, Yeates D, Gill LE. Depression and anxiety in people with inflammatory bowel disease. J Epidemiol Community Health 2001;55:716-20

75. Karling P, Danielsson A, Adolfsson R, Norrback KF. No difference in symptoms of irritable bowel syndrome between healthy subjects and patients with recurrent depression in remission. Neurogastroenterol Motil 2007;19:896-904.

76. Blomhoff S, Spetalen S, Jacobsen MB, Malt UF. Phobic anxiety changes the function of brain-gut axis in irritable bowel syndrome. Psychosom Med 2001;63:959-65.

77. Padhy SK, Misra S, Sarkar S, Panigrahi M, Bung G. Comparison of psychiatric comorbidity in individuals with IBS and non-ulcer dyspepsia. Ind Psychiatry J 2015. [In press].

78. Pata C, Erdal ME, Derici E, Yazar A, Kanik A, Ulu O. Serotonin transporter gene polymorphism in irritable bowel syndrome. Am J Gastroenterol 2002;97:1780-4.

79. Camilleri M, Atanasova E, Carlson PJ, Ahmad U, Kim HJ, Viramontes BE, et al. Serotonin-transporter polymorphism pharmacogenetics in diarrhea-predominant irritable bowel syndrome. Gastroenterology 2002;123:425-32.

80. Kilpatrick LA, Labus JS, Coveleskie K, Hammer C, Rappold G, Tillisch $\mathrm{K}$, et al. The HTR3A polymorphism c. $-42 \mathrm{C}>\mathrm{T}$ is associated with amygdala responsiveness in patients with irritable bowel syndrome. Gastroenterology 2011;140:1943-51.

81. Alonso C, Guilarte M, Vicario M, Ramos L, Ramadan Z, Antolín M, et al. Maladaptive intestinal epithelial responses to life stress may predispose healthy women to gut mucosal inflammation. Gastroenterology 2008;135:163-172.e1.

82. Farnam A, Somi MH, Sarami F, Farhang S. Five personality dimensions in patients with irritable bowel syndrome. Neuropsychiatr Dis Treat 2008;4:959-62.

83. Drossman DA, Leserman J, Li Z, Keefe F, Hu YJ, Toomey TC. Effects of coping on health outcome among women with gastrointestinal disorders. Psychosom Med 2000;62:309-17.

84. Wrzesinska MA, Kocur J. The assessment of personality traits and coping style level among the patients with functional dyspepsia and irritable bowel syndrome. Psychiatr Pol 2008;42:709-17.

85. Portincasa P, Moschetta A, Baldassarre G, Altomare DF, Palasciano G. Pan-enteric dysmotility, impaired quality of life and alexithymia in a large group of patients meeting ROME II criteria for irritable bowel syndrome. World J Gastroenterol 2003;9:2293-9. 
86. Porcelli P, Bagby RM, Taylor GJ, De Carne M, Leandro G, Todarello O. Alexithymia as predictor of treatment outcome in patients with functional gastrointestinal disorders. Psychosom Med 2003;65:911-8.

87. Surdea-Blaga T, Baban A, Dumitrascu DL. Psychosocial determinants of irritable bowel syndrome. World J Gastroenterol 2012;18:616-26.

88. Drossman DA, Chang L, Schneck S, Blackman C, Norton WF, Norton NJ. A focus group assessment of patient perspectives on irritable bowel syndrome and illness severity. Dig Dis Sci 2009;54:1532-41.

89. Gomborone J, Dewsnap P, Libby G, Farthing M. Abnormal illness attitudes in patients with irritable bowel syndrome. J Psychosom Res 1995;39:227-30.

90. Lackner JM, Quigley BM, Blanchard EB. Depression and abdominal pain in IBS patients: The mediating role of catastrophizing. Psychosom Med 2004;66:435-41.

91. Chitkara DK, van Tilburg MA, Blois-Martin N, Whitehead WE. Early life risk factors that contribute to irritable bowel syndrome in adults: A systematic review. Am J Gastroenterol 2008;103:765-74.

92. Katon W, Sullivan M, Walker E. Medical symptoms without identified pathology: Relationship to psychiatric disorders, childhood and adult trauma, and personality traits. Ann Intern Med 2001;134(9 Pt 2):917-25.

93. Koloski NA, Talley NJ, Boyce PM. A history of abuse in community subjects with irritable bowel syndrome and functional dyspepsia: The role of other psychosocial variables. Digestion 2005;72:86-96.

94. Videlock EJ, Adeyemo M, Licudine A, Hirano M, Ohning G, Mayer M, et al. Childhood trauma is associated with hypothalamic-pituitary-adrenal axis responsiveness in irritable bowel syndrome. Gastroenterology 2009;137:1954-62.

95. White DL, Savas LS, Daci K, Elserag R, Graham DP, Fitzgerald SJ, et al. Trauma history and risk of the irritable bowel syndrome in women veterans. Aliment Pharmacol Ther 2010;32:551-61.

96. Mayer EA, Naliboff BD, Chang L, Coutinho SV. Stress and the Gastrointestinal Tract V. Stress and irritable bowel syndrome. Am J Physiol Gastrointest Liver Physiol 2001;280:G519-24.

97. Drossman DA. The role of psychosocial factors in gastrointestinal illness. Scand J Gastroenterol Suppl 1996;221:1-4.

98. Whitehead WE, Crowell MD, Robinson JC, Heller BR, Schuster MM. Effects of stressful life events on bowel symptoms: Subjects with irritable bowel syndrome compared with subjects without bowel dysfunction. Gut 1992;33:825-30

99. Vanuytsel T, van Wanrooy S, Vanheel H, Vanormelingen C, Verschueren S, Houben E, et al. Psychological stress and corticotropin-releasing hormone increase intestinal permeability in humans by a mast cell-dependent mechanism. Gut 2014;63:1293-9.

100. Iorio N, Makipour K, Palit A, Friedenberg FK. Post-traumatic stress disorder is associated with irritable bowel syndrome in African Americans. J Neurogastroenterol Motil 2014;20:523-30.

101. Hu YJ, Wang YD, Tan FQ, Yang WX. Regulation of paracellular permeability: Factors and mechanisms. Mol Biol Rep 2013;40:6123-42.

102. Öhman L, Törnblom H, Simrén M. Crosstalk at the mucosal border: Importance of the gut microenvironment in IBS. Nat Rev Gastroenterol Hepatol 2015;12:36-49.

103. Mendeloff AI, Monk M, Siegel CI, Lilienfeld A. Illness experience and life stresses in patients with irritable colon and with ulcerative colitis An epidemiologic study of ulcerative colitis and regional enteritis in Baltimore, 1960-1964. N Engl J Med 1970;282:14-7.

104. Fava GA, Pavan L. Large bowel disorders. I. Illness configuration and life events. Psychother Psychosom 1976-1977;27:93-9.

105. Drossman DA, Sandler RS, McKee DC, Lovitz AJ. Bowel patterns among subjects not seeking health care. Use of a questionnaire to identify a population with bowel dysfunction. Gastroenterology 1982;83:529-34.

106. Drossman DA, McKee DC, Sandler RS, Mitchell CM, Cramer EM, Lowman BC, et al. Psychosocial factors in the irritable bowel syndrome. A multivariate study of patients and nonpatients with irritable bowel syndrome. Gastroenterology 1988;95:701-8.

107. Creed F, Craig T, Farmer R. Functional abdominal pain, psychiatric illness, and life events. Gut 1988;29:235-42.

108. Dinan TG, O'Keane V, O'Boyle C, Chua A, Keeling PW. A comparison of the mental status, personality profiles and life events of patients with irritable bowel syndrome and peptic ulcer disease. Acta Psychiatr Scand 1991;84:26-8.

109. Levy RL, Cain KC, Jarrett M, Heitkemper MM. The relationship between daily life stress and gastrointestinal symptoms in women with irritable bowel syndrome. J Behav Med 1997;20:177-93. 